\title{
A Brief Study of Energy Efficiency in Alternative Routes of Extraction of Aluminium and Magnesium
}

\author{
Mainak Saha ${ }^{\#}$ \\ \#Department of Metallurgical and Materials Engineering,National Institute of Technology,Durgapur,India
}

\begin{abstract}
The Hall-Héroult process for the electrolytic reduction of alumina was developed at the end of the 19 th century and is still currently the only industrial process for the production of aluminium. Today this process is ranked among the most energy and CO2 intensive industrial processes, consuming about $1 \%$ of the globally produced electric energy and producing $2.5 \%$ of the world's anthropogenetic GHG emissions. The direct carbothermic reduction of alumina has been proposed as an alternative process which can substantially improve the sustainability of primary aluminium production Thermochemical calculations predict that by carrying out the carbothermic reduction under vacuum, not only will the required reaction temperature be considerably lowered, but also the formation of gaseous Al should occur without the accompanying formation of $\mathrm{Al} 2 \mathrm{O}, \mathrm{Al4C}$, and of Al-oxycarbides. Alternatively, liquid Al can be produced by a combination of high temperatures and high excess of carbon thereby again avoiding carbide and sub-oxide formation. The implementation of such carbothermic reduction processes in aluminium production may lead to energy savings of up to $21 \%$, GHG emissions reductions of up to $52 \%$ and exergy efficiency increase of up to 10 percentile points. Additionally, the prospect of utilizing concentrated solar energy to provide process heat can render the primary aluminium production truly sustainable. Magnesium has a number of applications, such as a light alloy in in the automotive industry an alloying element in aluminium alloys, die casting(32\%), steel desulphurisation (13\%), and other applications as an industrial chemical (14\%) (USGS,2009). Aluminium industry utilizes magnesium as alloying ingredients to increase the strength, ductility and corrosion resistance of aluminium alloys. Magnesium's use in both aluminium and steel production strongly links its demand to these two other metal commodities. The usage of magnesium has historically been limited by relatively high cost of production and associated energy costs. There have also been scientific issues around alloy development, in particular, increasing creep resistance for drive train applications and improving corrosion resistance.
\end{abstract}

Keywords: Direct carbothermal process for Al;Mintek process for Mg;Solid Oxide process for Mg;HallHeroult's process; Magnetherm process for Mg;Arc Attachment Zone(AAZ)

\section{Introduction}

The production of Aluminium from its ores at present relies on the Bayer (alumina production) and the Hall- Heroult (Al production) process. The cost associated with alumina production and apparent disadvantages like high energy consumption of the Hall-Heroult process have led to intensive research to find alternative routes for Al production. The direct has been thoroughly investigated as an alternative technique. Another alternative includes the indirect carbothermal reduction route where alumina (or aluminous ores) is first reduced to intermediate Al compounds before reduced further to Al. Magnesium is a light metal that used in structural applications, and also used as additive in chemical and metallurgical industries. Magnesium production consumes greater energy than other metal production routes due to its oxidechemical stability. In particular, the Pidgeon process as the dominant production route in the world has high energy consumption which leads to high a Global Warming Potential. Thus, technology improvement is essential to achieve lower energy usage and a sustainable future. The current dominant route for producing magnesium is via the Pidgeon and electrolytic processes,requiring intensive energy and high capital costs.So,energy efficiency of alternative routes for $\mathrm{Mg}$ extraction such as Mintek and solid oxide membrane processes(SOM) along with Direct carbothermal process(only) for $\mathrm{Al}$ extraction is discussed and highlighted in this paper.

\section{A. DIRECT CARBOTHERMAL REDUCTION PROCESSES FOR EXTRACTION OF AI}

The direct carbothermal reduction of alumina to aluminium has potential for greater greenhouse gases emission, compared to the Hall Heroult process. It is well established that direct carbothermal reduction of iron oxide, through blast furnace technology, offers far greater productivity and energy efficiency than any comparable electrolytic process. One major difficulty associated with prior art carbothermic reduction processes is that they have relied upon electrically heated furnaces as a major source of energy. It is well known that when electricity is produced by combustion of fossil fuels, only a minor portion of the heat value of the fuel is recovered as electricity. Accordingly, prior art electrically powered processes for carbothermic reduction of aluminum fromAl are relatively wasteful of energy. In the first step of this method aluminum carbide is 
produced, and a second step in which aluminum carbide and alumina are reacted at a temperature higher than that of the first step to yield aluminum. Heated gaseous carbon monoxide evolved in both steps is used to preheat the reactants. However, rather than providing a stack reactor, first step is performed in a low temperature zone and the second step in a high temperature zone, with the two zones being at different locations on generally the same level. The reaction is performed by circulating a stream of molten slag through successive low and high temperature zones. The reactants are not heated by partial combustion of carbon so that a major proportion of energy requirements must be met by electricity. Any process that starts with alumina to make aluminum has the same theoretical energy requirement. Different processes do not offer any theoretical energy advantage.However, they do offer significant tradeoffs between efficiencies, emissions, footprints, and sources of input energy (electricity, carbon, and fuels). Molten aluminum is the product of primary reduction processes. This paper calculates the theoretical minimum energy by assuming the reactants enter and the by products leave the system at room temperature and that molten aluminum leaves the system at $960^{\circ} \mathrm{C}$. Changes in the operating temperature of a cell have a minor effect on the theoretical energy requirements.For example, operating changes of $100^{\circ} \mathrm{C}$ in aHall-Héroult cell, operating in the range of $700^{\circ} \mathrm{C}$ to $1,100^{\circ} \mathrm{C}$, result in less than a $1 \%$ change. Some studies assume that the gasesevolved during reduction leave the system at the molten metal temperature. In these studies, the theoretical minimum is $2.5 \%$ to $3 \%$ higher.Theoretically, it is possible to capture all theenergy associated with these gaseous emissions. Three energy factors must be examined in the production of aluminum; energyrequired to drive the reduction reaction forward, energy required to maintain the system at constant pressure and temperature, and energy required to change the temperature of the reactants and/or products. The thermodynamics and chemical equilibrium of reactions aredescribed by the Gibbs equation: $\Delta \mathrm{G}=$ $\Delta \mathrm{H}-\mathrm{T} \Delta \mathrm{S}$. The energy required to drive the reaction forward is the Gibbs free energy $(\Delta \mathrm{G})$. For alumina reduction, $\Delta \mathrm{G}$ is less than the heat of reaction $(\Delta \mathrm{H})$ and additional energy $(\Delta \mathrm{H}-\Delta \mathrm{G})$ must be added to the system to maintain the system temperature. Otherwise, the system would cool as the reaction progresses. (Reduction cells operate at atmospheric conditions and no pressure change results from the reduction.) The energy required to change the temperature of reactants and products is calculated from their heat capacities $(\mathrm{Cp})$. The theoretical Hall-Héroult reaction is assumed to occur under perfect conditions, where there are no reverse reactions, no parasitic reactions consuming additional anode carbon, no limitations to the ionic species reacting at the electrodes, and no heat or energy losses external to the system. The energy required to drive the reaction forward $(\Delta \mathrm{G})$ is $5.11 \mathrm{kWh} / \mathrm{kg}$, the thermal energy required to maintain the system temperature is $0.49 \mathrm{kWh} / \mathrm{kg}$ and the thermal energy associated with the molten aluminum is $0.39 \mathrm{kWh} / \mathrm{kg} \mathrm{Al}$. The theoretical minimum energy requirement is $5.99 \mathrm{kWh} / \mathrm{kg}$ Al. Faraday.s law provides the minimum amperage requirement for electrolytic reduction, 2,980 Ah/ $\mathrm{kg} \mathrm{Al}$. The Gibbs free energy divided by the Faraday amperage provides the minimum voltage required to drive the reaction forward. Cell voltage and current efficiency are variables that are controllable by design and they determine the electrical power required for reducing alumina. In practice, electrolytic cells have significant inefficiencies and operate above the minimum voltage requirement. This excess voltage provides the thermal energy required to maintain system equilibrium $(\Delta \mathrm{H}-\Delta \mathrm{G})$ and to produce molten material (Cp).In actual carbon anode cell operations, current efficiencies of less than $100 \%$ result from reverse oxidation reactions between part of the aluminum metal that is dissolved in the cryolite and carbon dioxide gas. . The high current efficiency of existing technologies leaves little opportunity for lowering amperage. Since current efficiency is high, lowering cell voltage presents the best opportunities for improving energy efficiency. Carbon is consumed during the reaction process and gives the process a lower theoretical energy requirement $(7.32 \mathrm{kWh} / \mathrm{kg} \mathrm{Al})$ than the direct reduction of alumina. If an $85 \%$ thermal and $95 \%$ reaction efficiency were assumed a carbothermic reactor would require $9.07 \mathrm{kWh} / \mathrm{kg} \mathrm{Al}$, a $40 \%$ reduction in energy. Additional energy reduction could come from capturing the fuel value of the carbon monoxide byproduct.The carbothermic reaction results in the generation of carbon-based greenhouse gases (GHG), mainly carbon monoxide $(\mathrm{CO})$, at twice the rate of the Hall-Héroult reaction.However, the carbothermic process requires electricity only for heating and not for electrolysis. The total greenhouse gas (GHG) emissions from .utility-tometal. for the carbothermic process are roughly $8 \%$ less than a modern Hall-Héroult cell.

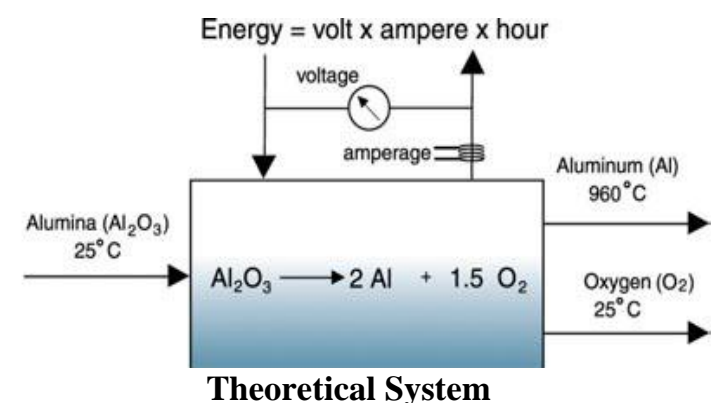




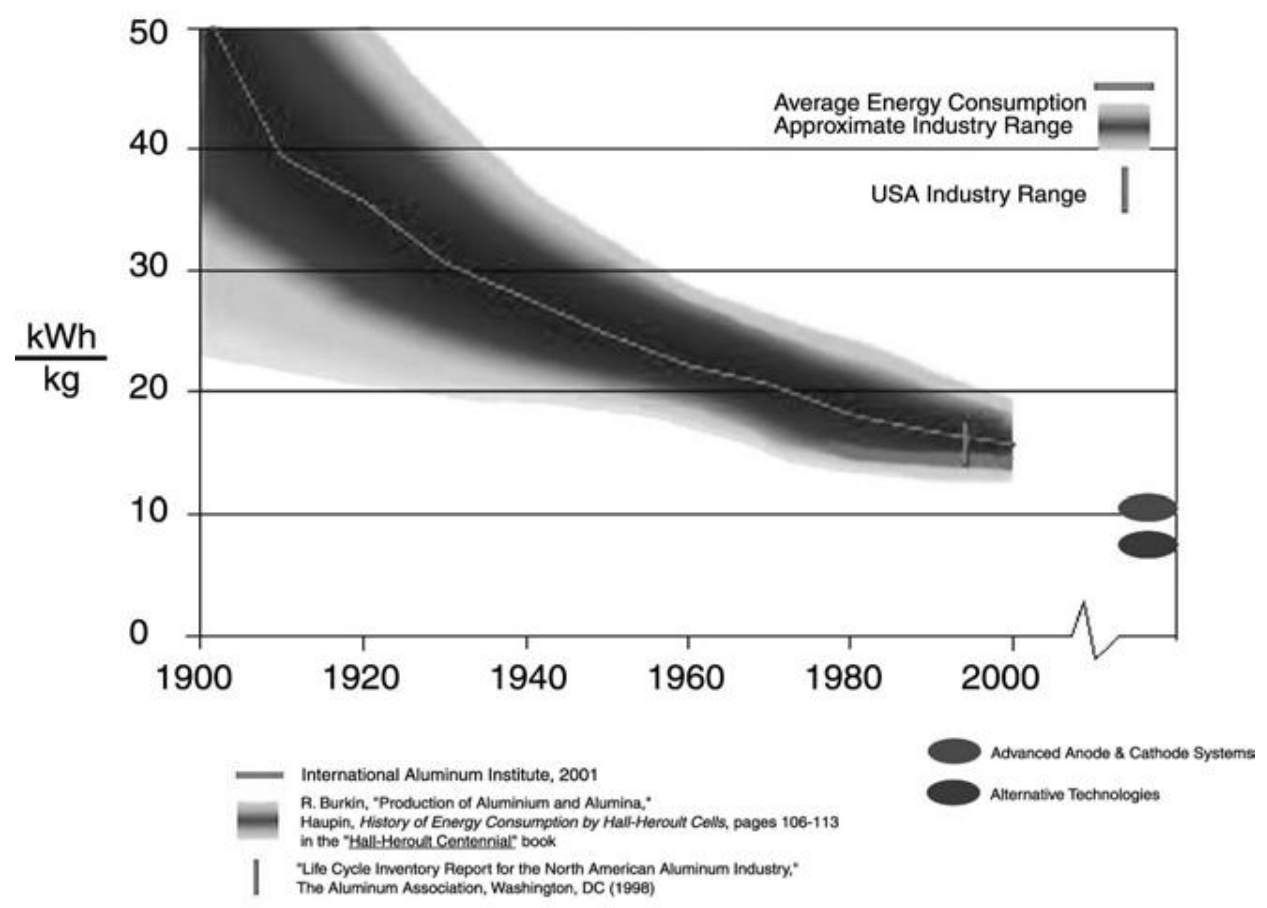

Source: Burkin

Primary Aluminum Electric Energy Consumption

Primary Aluminum Electric Energy Consumption 1900 to 2000, shows the significant electrical energy improvements made between 1900 and 2000. Onsite electricity use varies from less than $13 \mathrm{kWh} / \mathrm{kg} \mathrm{Al}$ for state-of-the-art plants up to more than $20 \mathrm{kWh} / \mathrm{kg} \mathrm{Al}$ (U.S. plants in 1995 averaged $15.4 \mathrm{kWh} / \mathrm{kg}$ Al (The Aluminum Association,1998)). Compared to theoretical values, U.S.facilities are averaging roughly $35 \%$ energy efficiency. There is a minimum cell amperage required to produce aluminum $(2980 \mathrm{Ah} / \mathrm{kg} \mathrm{Al})$.

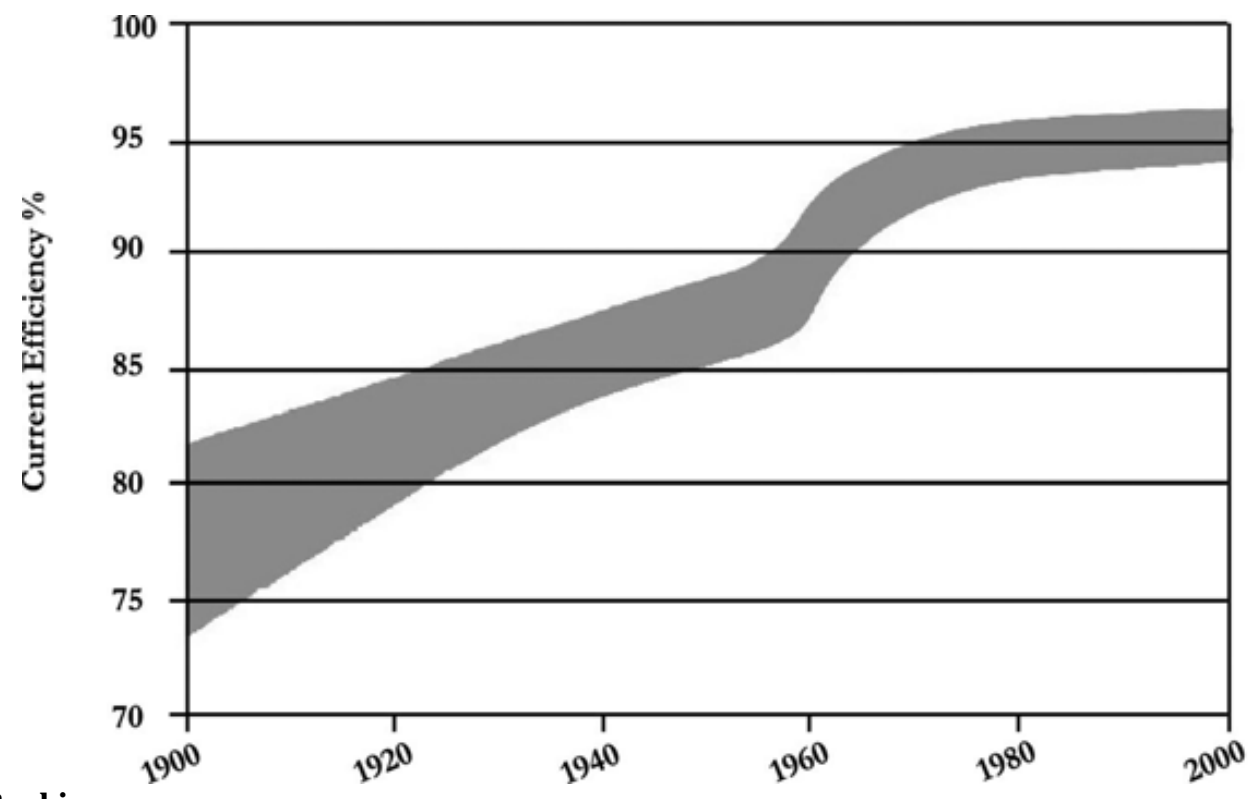

Source: Burkin

Hall-Héroult Cell Current Efficiency 


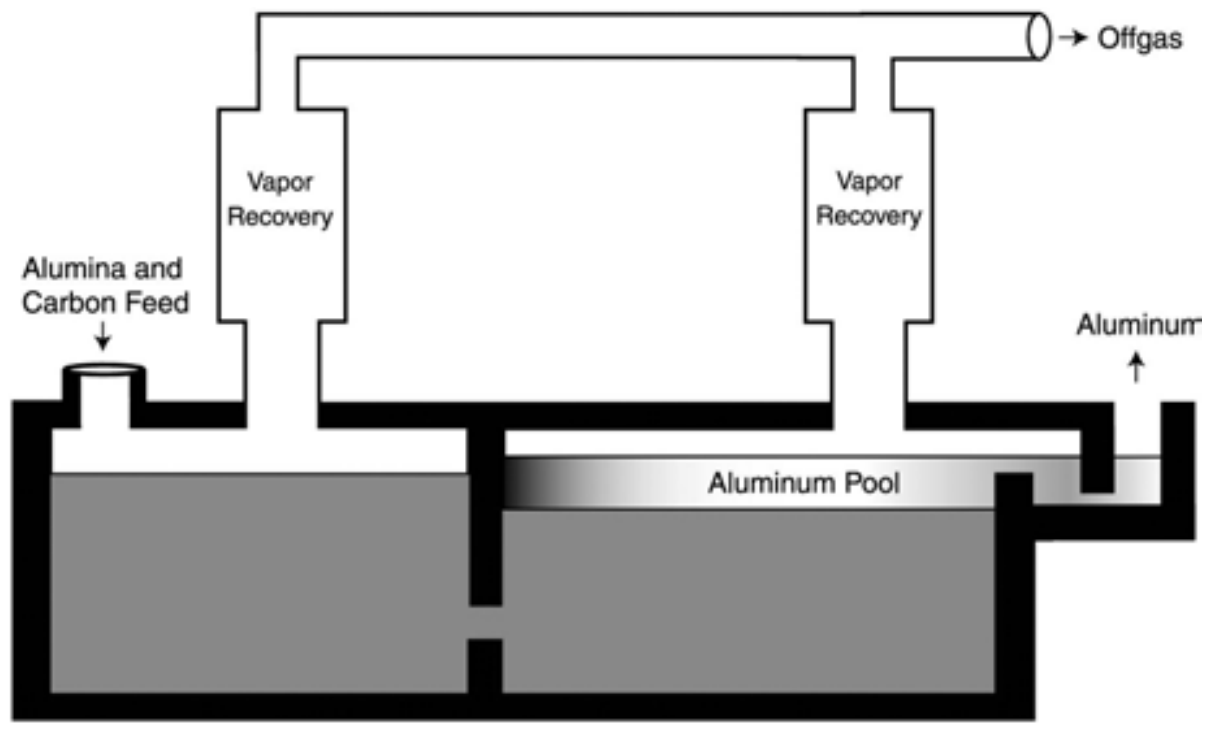

Carbothermic Reactor

\section{B. MINTEK PROCESS FOR EXTRACTION OF Mg}

The Mintek Process is a large scale batch silicothermic process operating at atmospheric pressure. It attempts to overcome the productivity and operational difficulties associated with an earlier large batch process called the Magnetherm process. Pechiney developed the Magnetherm process in the 1950s and operated at 1550 $\operatorname{deg} \mathrm{C}$ under vacuum. In this process, to achieve an economically acceptable level of magnesium extraction and rate of $\mathrm{Mg}(\mathrm{V})$ generation, the furnace operating temperature needs to be increased above that employed in Pechiney's Magnetherm processes . Electrical energy consumption could, therefore, be higher .In the process during DC-arc smelting of magnesium-containing raw materials at atmospheric pressure is influenced by several factors, including temperature, choice of feed recipe, slag depth relative to furnace diameter, and the reactions in the arc attachment zone (AAZ). As indicated previously, the furnace operating temperature needs to be above $1600^{\circ} \mathrm{C}$; it could be as high as $1800^{\circ} \mathrm{C}$ in order to achieve an economically acceptable degree of magnesium extraction and rate of extraction and to allow continuous slag tapping, yet keep the consumption of furnace electrical energy as low as possible. As the slag bath is not agitated externally, uniformity of the slag temperature could become an issue: segregation of high-melting slag components and their possible freezing on the furnace side-walls and/or on the hearth could take place. Were this to happen, continuous slag tapping might be interrupted.A simple way to overcome such a potential difficulty is by optimizing the ratio of slag depth to furnace internal diameter. A schematic of the $100 \mathrm{~kg} / \mathrm{h}$ magnesium pilot plant is shown in the next page . Theequipment consists of a $1.5 \mathrm{MW}$ (10kA) power supply, a DC arc furnace, a raw materialfeed system, a magnesium condenser, a combustion chamber, a gas-cleaning system, and certain other ancillary equipment. The airtight feed system consists of three surge binsn(upper bins) and three weigh bins (lower bins), varying in size from $60 l$ to $550 l$. Each pair of upper/lower bins is dedicated to deliver a specific raw material to the furnace. The feed system is designed to feed 250 to $500 \mathrm{~kg} / \mathrm{h}$ hot dolime (at up to $900^{\circ} \mathrm{C}$ ), 40 to $80 \mathrm{~kg} / \mathrm{h}$ ferrosilicon, and 15 to $60 \mathrm{~kg} / \mathrm{h}$ aluminium to produce 50 to $100 \mathrm{~kg} / \mathrm{h}$ magnesium vapour. The upper bins are provided with argon and vacuum lines for purging, after charging batches of raw materials to them. Airtight valves are positioned between each pair of bins. Vibratory feeders are used to charge the ferrosilicon and aluminium, while a rotary feeder is employed to feed the dolime into the furnace.The furnace consists of a refractory-lined cylindrical shell and a conical roof. The furnace has an internal diameter, at the slag level, of about $1200 \mathrm{~mm}$, and a shell diameter of $1900 \mathrm{~mm}$. The hearth area is lined with carbon blocks, while magnesiabased refractories are used for the hot face, above the slag level (due to the erosion of the side wall refractory, neutral slag recipe was employed to warm-up the furnace and to form a freeze lining, as will be discussed later) . The anode connection consists of two graphite rods, cemented into the carbon hearth-blocks. The graphite rods are further linked to the anode cables via water-cooled copper pins. The furnace shell is equipped with water spray cooling. Water-cooled panels are used at the conical roof, which is lined with alumina castable. The roof contains a central entry port for the graphite electrode, an offgas duct, and a feed port. The electrode seal consists of a flexible stainless-steel bellow. The off-gas port contains vermiculite based bricks, behind the alumina hot-face castable. 


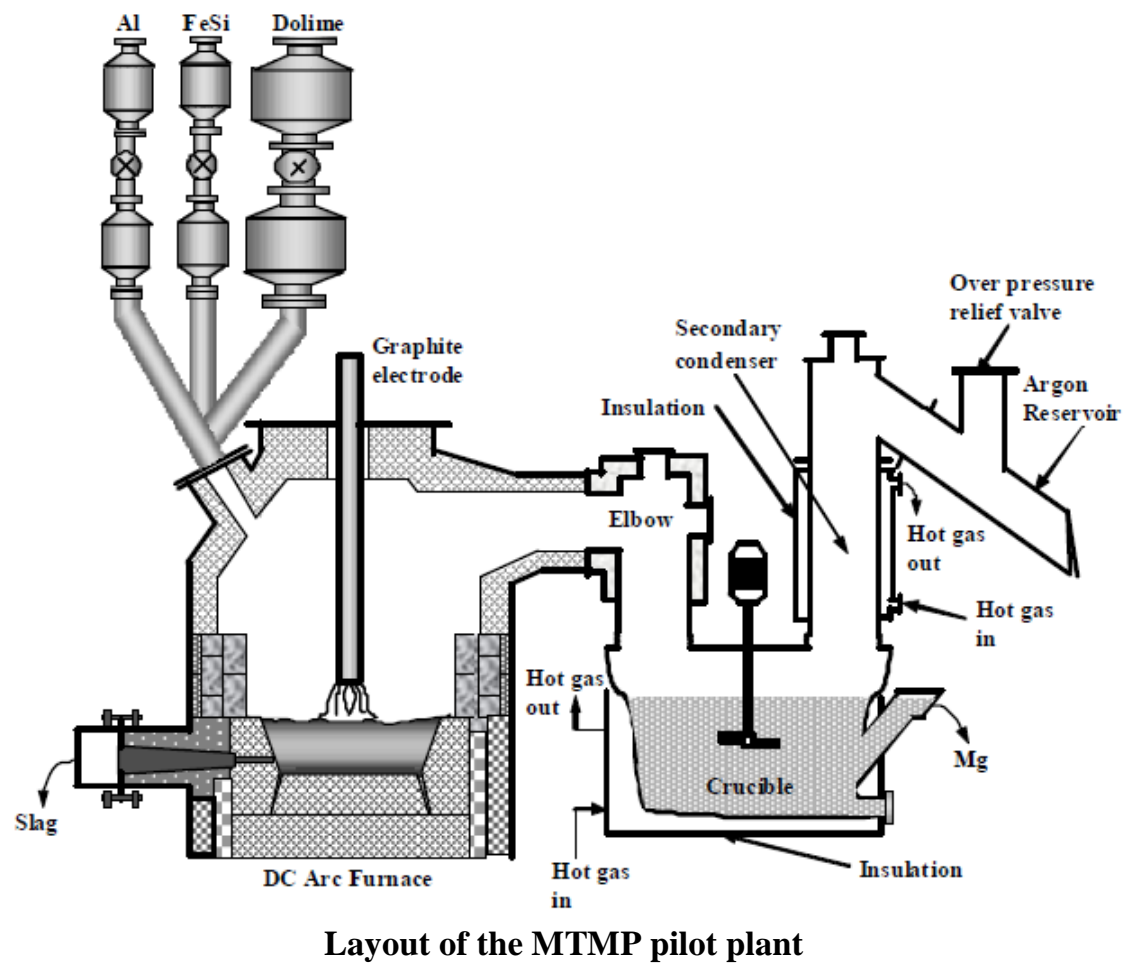

A radically new condenser designed based on certain principles in order to allow continuous (semicontinuous) operation of the facility for extended period of time. It allows the removal of the condensed magnesium along with any oxides that might be present. Flow restrictions and blockages in the condenser system are also dealt with online without interrupting magnesium production. The new condenser set-up includes an elbow section, a crucible, a secondary condenser, a stirrer, and plungers for the clearing of blockages. The top section of the condenser (elbow) incorporates a thermally insulating refractory material, between concentric 3Cr12 stainless steel sleeves (ferritic steel developed by Southern Africa Stainless Steel Development Association, SASSDA), with an inner diameter of $400 \mathrm{~mm}$. The elbow forms the connection between the furnace and the condenser crucible. The condenser crucible consists of a cylindrical steel shell, a dished bottom, and a flat top plate. The crucible is $1.2 \mathrm{~m}$ in diameter, $1.3 \mathrm{~m}$ high, and is made of $28 \mathrm{~mm}$ thick 3CR12 steel plate. The top section is widened to fit the inlet and outlet into a relatively small diameter crucible. The crucible contains an underflow/overflow arrangement, consisting of an inclined spout and an overflow box, in order to remove magnesium under sealed conditions.During operation the magnesium level is kept between the bottom and the middle of the overflow box, for effective operation of the condenser. The impeller of the stirrer is engineered to create a vortex in order to pull in oxides and magnesium vapour. The condenser crucible contains three baffles to break up the centrifugal motion that is induced by the stirrer, and to enhance mixing. A secondary condenser is connected behind the crucible and consists of a cylindrical 3CR12 steel pipe, 400mm in diameter, and $1.7 \mathrm{~m}$ long. The surface area of the secondary condenser is designed such that it is sufficient to condense all the magnesium vapour produced in the furnace. The condenser system also includes two propane burners for preheating of the condenser crucible and the secondary condenser, and for maintaining the condenser temperature at $650^{\circ} \mathrm{C}$ to $750^{\circ} \mathrm{C}$ during magnesium production. Three hydraulic plungers are included for the on-line cleaning of blockages in the crossover duct between the furnace and the condenser, in the elbow, and in the secondary condenser. The off-gas system consists of an argon reservoir (mild steel, 350mm diameter), equipped with a flap valve arrangement devised to prevent a large amount of air from entering the condenser via the combustion chamber, and a pressure release disc. The combustion chamber is refractory lined and equipped with a pilot burner to oxidize any uncondensed magnesium, carbon monoxide and hydrogen. The reverse-pulse bag-filter is intended to separate the oxidized magnesium from the off-gas, and to vent only clean air and argon to the atmosphere. Auxiliary equipment includes a condenser cleaning station, drill machine-mud gun assembly for slag tapping, etc. The dolime is heated up in an electrically operated kiln. The kiln temperature varies between 1000-1100degC, and was rotated at 3.0-3.5rpm. The feed rate is varied in order to match the furnace requirements and ranged from $250-400 \mathrm{~kg} / \mathrm{h}$. The heated dolime is collected in refractory-lined transfer bins and then discharged into the furnace feed system. Temperatures taken in the dolime upper hopper indicated a dolime temperature of 550-630degC, as compared to 640-750degC measured at the kiln discharge. The furnace total feed rate averages about $525 \mathrm{~kg} / \mathrm{h}(10.7 \% \mathrm{FeSi}, 5.5 \% \mathrm{Al}$, the balance being dolime $)$ and the feed duration is about 
2.5 hours, giving a batch size of $1300 \mathrm{~kg}$. The feed recipe is selected based on the relative ease of tapping of the resulting slag at the temperatures employed. Commercially, the recipe will be largely dictated by the overall economics of the process. About 30 tons of magnesium producing recipe have been processed over 22 feedingtapping operations, where 24 tons of slag is produced. The furnace energy losses averages about $360 \mathrm{~kW}$. The operating power is about $780 \mathrm{~kW}$, on average, and varies between 680 and $870 \mathrm{~kW}$, depending on the feed rate, furnace energy losses, and the dolime temperature, as measured in its weigh bin. An operating voltage of 180$200 \mathrm{~V}$ is employed during the smelting period. The powervoltage operating ranges results in an arc length of $100-250 \mathrm{~mm}$ (shorter arc at the end of the batch where the slag depth is $430-460 \mathrm{~mm}$, longer arc at the beginning of the feeding period where the slag depth is $80-150 \mathrm{~mm}$ ). It is interesting to note that silicon utilisation (proportion of the silicon metal in the feed that reacts to produce magnesium vapour) varies between 84 and $88 \%$. The lower value has been derived from the slag mass and its average $\mathrm{SiO} 2$ content, while the higher figure is based on the Si-content in the tapped residual $\mathrm{FeSi}$ and assuming that all the iron in the feed reports to the residual FeSi. In addition, the electrode consumption is determined at $0.89 \mathrm{~kg} / \mathrm{MWh}$. Note that a $200 \mathrm{~mm}$ diameter graphite electrode is used, and the electrical current density averages $13.7 \mathrm{~A} / \mathrm{cm} 2$ during the campaign. This electrode consumption value is relatively low and could contribute towards improving the overall plant availability in a commercial installation, as electrode addition would be less frequent. In addition, the usage of special magnesium coalescing agents (AlF3, for example) in the refining stage may be significantly reduced, as less carbon would be present in the crude metal.

\section{SOLID-OXIDE MEMBRANE PROCESS FOR EXTRACTION OF Mg}

The Solid Oxide Membrane (SOM) process can be alternative to electrolytic process. In this process, reduction of magnesium oxide dissolved in fluoride-based electrolytes $(\mathrm{MgF} 2-\mathrm{CaF} 2-\mathrm{MgO})$ is carried out by passing electric current at 1150 to $1300 \mathrm{degC}$. When electrical current is applied, magnesium oxide dissociates into magnesium and oxygen. Oxygen ions are pumped out through Yttrium Stabilised Zirconia (YSZ) membrane to the anode. There are several scientific challenges in the SOM process. There are several scientific challenges in the SOM process. The selection of fluxes is crucial since the YSZ membrane should not dissolve into the $\mathrm{MgF} 2-\mathrm{CaF} 2-\mathrm{MgO}$ flux. The leakage of current in the cell because of oxygen impurity in the cell is also an issue. The engineering challenges regarding thermal shock and mechanical failure is a problem since the membrane used is the most expensive part of the SOM cell (Krishnan et al.,2005). The energy efficiency of the present process is attributed, in part, to the combination of two steps, one in which a metal oxide is reduced to form highly reactive metal and another in which a metal compound of interest is reduced while the highly reactive metal is oxidized. In one or more embodiments, it takes significantly less electrical energy to reduce the highly reactive metal and use it to produce the desired metal (or metal compound) from the metal compound of interest than it does to reduce the metal compound of interest to produce the desired metal (or metal compound) in an alternate, single-step process. This is because in the first step of the proposed multi-step process, the energy used to reduce the metal oxide to form the highly reactive metal is less than energy that would otherwise be used to directly reduce the metal of interest in a comparable single-step electrolysis process (such as a direct SOM electrolysis which is energy intensive). And, in the second step of the proposed multi-step process, no substantial amount of energy is needed to reduce the metal of interest because the highly reactive metal facilitates a chemical reaction. In sum, less energy is used to reduce a selected amount of the metal of interest than would be used in a comparable single-step electrolysis process. The reported energy demand is $10 \mathrm{kWh} / \mathrm{kg}$ $\mathrm{Mg}$.

Chemical Stability of Selected Oxide

\begin{tabular}{|l|c|c|}
\hline \multicolumn{1}{|c|}{ Reaction } & $\begin{array}{c}\text { Gibbs Free Energy }(\Delta \mathrm{G}) \text { at } 25{ }^{\circ} \mathrm{C} \\
(\mathrm{MJ} / \mathrm{kg} \mathrm{metal})\end{array}$ & $\begin{array}{c}\text { Enthalpy Formation }(\Delta \mathrm{H}) \text { at } 25 \\
{ }^{\circ} \mathrm{C}(\mathrm{MJ} / \mathrm{kg} \text { metal })\end{array}$ \\
\hline $2 \mathrm{Mg}+\mathrm{O}_{2} \rightarrow \mathrm{MgO}$ & -23.42 & 24.76 \\
\hline $2 \mathrm{Al}+3 / 2 \mathrm{O}_{2} \rightarrow \mathrm{Al}_{2} \mathrm{O}_{3}$ & -29.3235 & 31.2 \\
\hline $2 \mathrm{Fe}+3 / 2 \mathrm{O}_{2} \rightarrow \mathrm{Fe}_{2} \mathrm{O}_{3}$ & -6.66 & 7.30 \\
\hline
\end{tabular}

The chemical stability of an oxide compound can be reflected by the Gibbs free energy while the enthalpy formation determines the minimum energy requirement of a process. The Gibbs energy of magnesium oxide is lower than iron oxide, which indicates that magnesium oxide is more stable and requires more energy to extract the metal. The difference between the theoretical energy requirements and the actual energy usage reflects the different aspects of the process route. The energy efficiency of ferrosilicon electric arc furnace is only $51.5 \%$ while the efficiency of coal fired furnace is $12 \%$. The Pidgeon process urgently needs improvement in order to reduce energy consumption and greenhouse gas emissions. Improvement that has been proposed includes utilisation of cleaner energy source (e.g. natural gas or producer gas) and integrating small smelters to improve raw material and energy efficiency. The Solid Oxide Process(SOM) process has a lower Global 
Warming Potential compared to the Pidgeon process (47.3 $\mathrm{kg} \mathrm{CO} 2 / \mathrm{kg} \mathrm{Mg}$ to $62.7 \mathrm{~kg} \mathrm{CO} 2 / \mathrm{kg} \mathrm{Mg}$ ), but suffers from low productivity and high capital costs. The development of new high productivity pyrometallurgical processes by CSIRO and Mintek may provide the route by which Western countries, such as Australia, could develop an environmentally and economically acceptable route to Magnesium production.

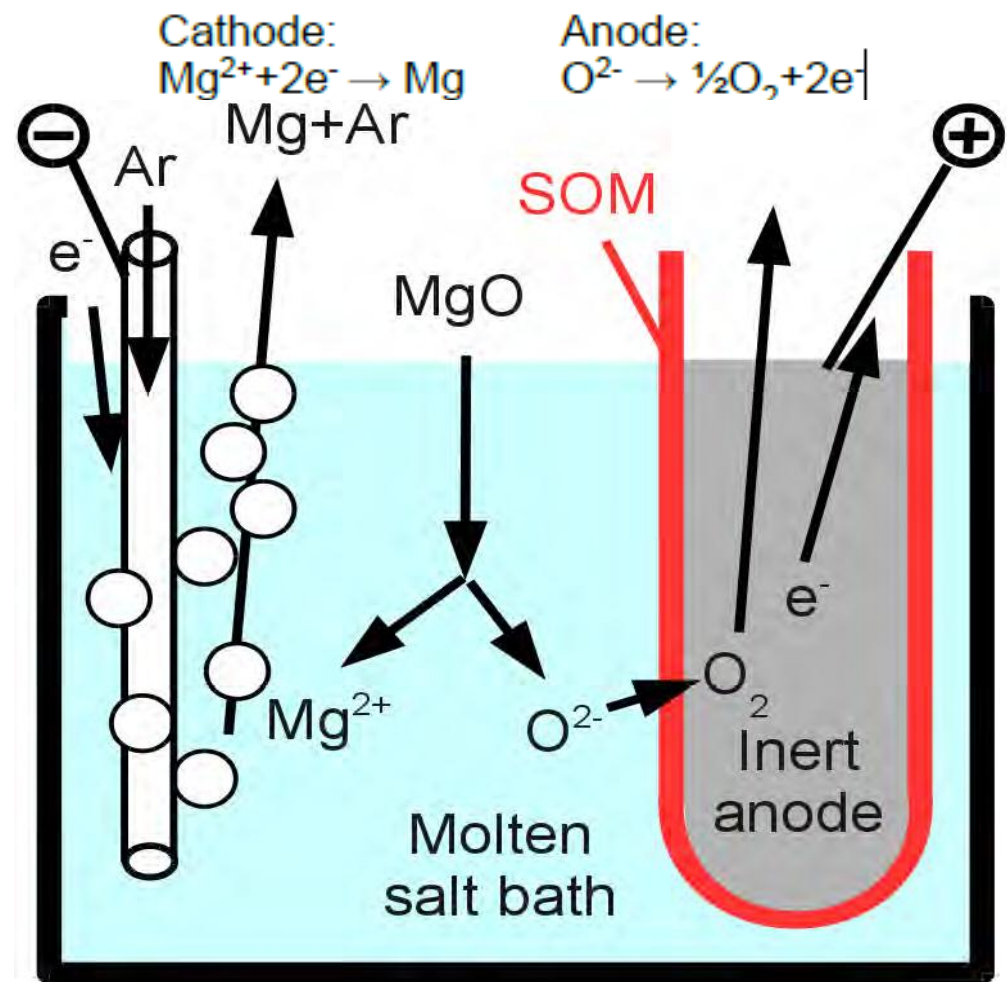

Priimary representation of the SOM process

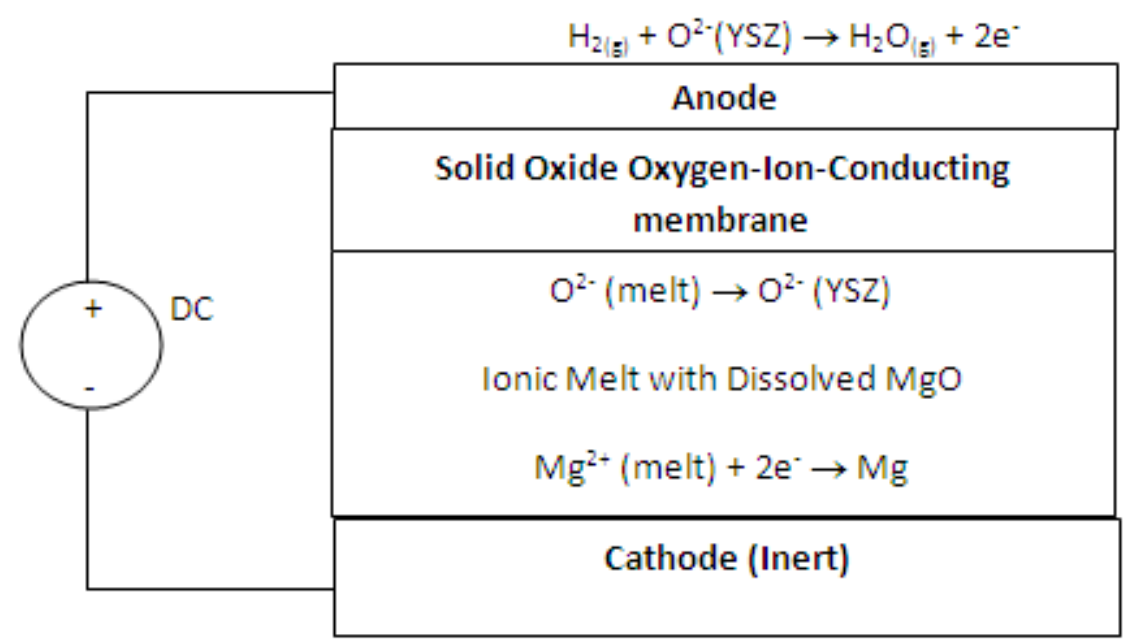

The SOM Process for Magnesium Production (Pal et al., 2001)

\section{Conclusions And Discussions}

As compared to Bayer's and Hall-Heroult's process ,energy requirements carbothermic production of $\mathrm{Al}$ can reduce energy requirements $35 \%$ below those of the best Bayer-Hall technology. In case of $\mathrm{Mg}$ extraction considering Mintek process, one way of minimizing energy requirements is by charging the dolime and/or magnesia as hot as possible.Also, Magnesium extraction and extraction rate are dependent, in part, on the operating temperature and the feed recipe used; they need to be optimized in order to improve the economics of the process. For prompt tapping from DC arc smelter and for low cleaning and refining costs the condensed metal should contain as little solids as possible. Magnesium extraction and extraction rate are dependent, in part, on the operating temperature and the feed recipe used; they need to be optimized in order to improve the 
economics of the process. For this purpose, the furnace needs to be operated in such manner as to produce and deliver almost pure magnesium vapour to the condenser.Capturing the volatilized magnesium in a liquid state is crucial to the continuous operation of an industrial facility. Better magnesium recoveries in the condenser where the reversion reaction is minimized

$\mathrm{CO}+\mathrm{Mg}(\mathrm{V})=\mathrm{MgO}+\mathrm{C}[1]$

In this method, the coalescence of the condensed magnesium droplets is adversely affected by the presence of carbon. Condensation to a liquid phase reduces the energy requirements in the cleaning and refining stages, as re-melting of the crude magnesium is not required.

\section{Acknowledgement}

The author would like to express appreciation for the support of the Department of Metallurgical and Materials Engineering, NIT Durgapur.

\section{References}

[1]. S. Namboothiri, M. P. Taylor, J. J. J. Chen, M. M. Hyland, M. Cooksey, "Aluminium Production Options with a Focus on the Use of a Hydrogen Anode: A Review”, Asia-Pacific Journal of Chemical Engineering, Vol.2, (2007), pp. 442-7.

[2]. I.M. Morsi, K.A. El Barawy, M.B. Morsi, S.R. Abdel-Gawad, Silicothermic reduction of Dolomite Ore under Inert Atmosphere, Canadian Metallurgical Quarterly, Vol. 14, No. 1,(2002),p.15.

[3]. Brooks, G., Trang, S., Witt, P., Khan, M.N.H , Nagle, M, 'Carbothermic Route to Magnesium', Journal of Minerals, Metals and Materials Society, Vol.58, no. 5, p.51-55.

[4]. R.T. Jones, Computer Simulation of Pyrometallurgical Processes, Proceedings of the Twentieth International Symposium on the Application of Mathematics and Computers in the Minerals,Industries, Vol. 2,( 1987),p.265.

[5]. Cherubini, F., Raugei, M., Ulgiati, S. (2008), 'LCA of Magnesium Production.Technological Overview and Worldwide Estimation of Environmental Burdens',Resources Conservation \& Recycling, vol.52, no. 8-9, p. 1093-1100.

[6]. Jenkins, D.H., Sheehan, G.J. ,Frost, M.T. (2009), 'Piloting the Australian MagnesiumProcess', Mineral Processing and Extractive Metallurgy (Trans. Inst. Min Metall. C), vol.118, no. 4, p. 205-213.

[7]. Kipouros, G.J. \& Sadoway, D.R. (1987) Advances in Molten Salt Chemistry.

[8]. Koenig, R., Baker, G. , Goebel, B. (2002) 'The Stanwell Magnesium Project - Providing New Environmental Standards for Magnesium Production', Green Processing Conference 2002, Cairn, The Australian Institute of Mining and Metallurgy p. 85-89

[9]. R.A. Sharma: "Method for Producing Aluminum Metal from Aluminum Trichloride", US Patent 6,066,247, 2000.

[10]. S. Wilkening: "Process for Producing Aluminium by Molten Salt Electrolysis", US Patent 4,919,771, 1990.

[11]. K.M. Tomaswick: "Low Temperature Aluminum Production", US Patent 6,428,675, 2002.

[12]. J.C. Terry, A. Lippman, R. F. Sebenik, , H. G. Harris: "Reduction of Aluminum Chloride by Manganese", US Patent 3,900,312, 1975.

[13]. H.N. Sinha: "Production of Anhydrous Aluminium Chloride", US Patent 4,264,569, 1981.

[14]. H.P. Mueller, H. Alder, G. Zhuber-Okrog: "Process for the Production of Aluminium Chloride", US Patent 4,289,735, 1981. 